\title{
Trends in risk factors chronic diseases, according of health insurance, Brazil, 2008-2013
}

Deborah Carvalho Malta ${ }^{1}$

Regina Tomie Ivata Bernal ${ }^{2}$ Martha Oliveira ${ }^{3}$

\footnotetext{
${ }^{1}$ Escola de Enfermagem, Departamento de Enfermagem MaternoInfantil e Saúde Pública, Universidade Federal de Minas Gerais. Av. Alfredo Balena 190, Santa Efigênia. 30130-100 Belo Horizonte MG Brasil. dcmalta@uol.com.br ${ }^{2}$ Núcleo de Pesquisas Epidemiológicas em Nutrição e Saúde, Faculdade de Saúde Pública.

${ }^{3}$ Agência Nacional de Saúde Suplementar.
}

\begin{abstract}
This article aims to compare the trends for risk and protective factors for NCD in the population with and without health insurance. Anal$y$ sis of temporal trends of the Vigitel phone survey, collected annually in adult population. Were used analyzed the temporal series of variables referent to risk and protective factors for NCD, from 2008 to 2013. Variables were compared according to the possession or not of health insurance using simple linear regression model. There was a reduction in the prevalence of smoking in the population with and without health insurance, in $0.72 \%$ and $0,69 \%$ per year respectively. The consumption of fruits and vegetables grew 0,8\% and $0.72 \%$ per year respectively among the population with and without health insurance. Physical activity in leisure time increased $1.17 \%$ and $1.01 \%$ per year among population with and without health insurance. Excess weight increased in $1.03 \%$ and obesity in $0.74 \%$ p.y in the population with health insurance and $1.53 \%$ and $0.95 \%$ p.y without health insurance. Mammography increased 2.4\% in the population without health insurance. Vigitel monitoring showed improvement in the indicators in the population with and without health insurance.

Key words Non-communicable diseases, Health insurance, Trends, Smoking, mammography
\end{abstract}




\section{Introduction}

Noncommunicable diseases (NCDs) - particularly cardiovascular and chronic respiratory diseases, along with neoplasms and diabetes - cause a high number of premature deaths and loss of quality of life, in addition to exerting significant economic and social impacts ${ }^{1}$.

The NCD epidemic has preferentially affected low-income populations because they are most exposed to risk factors and have the least access to healthcare services ${ }^{1}$.Studies indicate differences in the distribution of the morbidity, mortality and risk factors of NCDs according to socioeconomic conditions, access to services and consumer purchasing patterns, among other factors $^{1-3}$.

As a function of their global relevance, a high-level meeting of the United Nations General Assembly held in 2011 summoned heads of state and countries, and global agreements for addressing NCDs were established. The agreements and targets include a $25 \%$ reduction in premature mortality from NCDs by 2025 and reductions in specific risk factors, such as smoking and physical inactivity ${ }^{4}$.

Within that context, monitoring the trends exhibited by NCDs and their risk factors at the national and regional levels and per population segments and sectors is relevant for identifying social vulnerabilities and ways to correct them ${ }^{4,5}$.

Data from the National Household Sample Survey (Pesquisa Nacional de Amostra de Domicílios - PNAD) show that in Brazil, individuals with higher family income have better access to healthcare services and medical consultations $s^{6}$. In addition, the higher the family income, the higher the odds are for individuals to have access to privatehealth insurance coverage. Thus, in $2008,84 \%$ of the population with income over 20 times the minimum wage had private health insurance coverage versus $3 \%$ of the low-income population ${ }^{6}$.

In the United States, specialized telephone surveys (e.g., the Behavioral Risk Factor Surveillance System [BRFSS]) indicate that the population with private health insurance tends to have wider access to preventive testsand exhibits a higher prevalence of protective factors, such as healthy eating and physical activity, and a lower prevalence of risk factors, such as smoking ${ }^{7,8}$.

Few studies have assessed this topic in Brazil; however, those studies that have, such as one conducted in Belo Horizonte, Minas Gerais, detected a significantly higher prevalence of risk factors in populations without private health insurance?. Studies conducted within the National System of Surveillance of Chronic Diseases by Telephone Survey (Sistema Nacional de Vigilância de Doenças Crônicas por Inquérito Telefônico Vigitel) found that the access to cancer screening tests is better among the population with private health insurance ${ }^{10}$, which further exhibits a larger prevalence of protective factors and a lower prevalence of risk factors ${ }^{10}$.

Starting in 2006, risk factors for NCDs began to be monitored in Brazil through Vigitel ${ }^{11}$. The survey is performed with the adult population ( $\geq 18$ years old) from all 26 state capitals and the Federal District on an annual basis ${ }^{10}$. The variable private health insurance was included in 2008, which allowed for new explorations relative to the population thus benefitted.

The present study compared the trends exhibited by the protective and risk factors for NCDs and reported morbidity and access to preventive tests between the population with or without private health insurance from all Brazilian capitals taken together from 2008 to 2013.

\section{Method}

This population-based cross-sectional study was conducted with the adult population $(\geq 18$ years old) from the 26 Brazilian state capitals and the Federal District. Vigitel surveys probabilistic samples of the adult population ( $\geq 18$ years old) based on the register of landline owners provided by the main telephone operating companies every year. Five thousand landlines are randomly selected from each city by lottery and are then divided into replicates (or subsamples) with 200 landlines each to identify the eligible ones, i.e., the active residential landlines. Once the eligibility of each landline is established, the resident to be interviewed is selected.

Vigitel databases from 2008 to 2013 were used. The raking ${ }^{11-13}$ technique was used to calculate post-stratification weights using an external source of the data for the Brazilian population. Estimates of age, gender and schooling for the projected population in the year of the study were used to calculate post-stratification weights. The raking technique uses the distribution of absolute frequencies of gender (male, female), age ranges ( 18 to 24,25 to 34,35 to 44,45 to 54 and 65 years old or older) and levels of schooling (zero to seven, eight to 10,11 to 13 , and 14 or more years of formal education), which are 
balanced according to the sample weights. The weights were calculated using Izrael et al.'s ${ }^{13} \mathrm{mac}$ ro sasRakinge.sas in the program. This procedure seeks to equate the distribution of the surveyed population to the one of the population of each state capital, as estimated by Vigitel.

The Vigitel questionnaire consists of approximately 90 questions on various subjects, including demographic and socioeconomic characteristics; dietary and physical activity patterns; reported body weight and height; tobacco and alcohol use; self-assessed state of health; and reported morbidity ${ }^{11}$.

The trends exhibited by the populations with or without private health insurance were compared, and the following risk factors for NCDs were analyzed:

a) Tobacco use: prevalence of smokers (\% smokers/number of interviewees).

b) Overweight (body mass index $-\mathrm{BMI} \geq 25$ $\left.\mathrm{kg} / \mathrm{m}^{2}\right)$ and obesity $\left(\mathrm{BMI} \geq 30 \mathrm{~kg} / \mathrm{m}^{2}\right)$.

c) Dietary intake: consumption of meat with visible fat (red meat with visible fat or chicken with skin); regular soft drink or artificial fruit juice intake (five or more days per week); recommended fruit, legume and vegetable intake (five or more daily portions five or more days per week); regular fruit, legume and vegetable intake (\% of adults who consume fruits and vegetables five or more days per week); and whole milk intake (\% of individuals who consume whole milk).

d) Recommended free-time physical activity (practice of mild-tomoderate-intensity physical activity 150 minutes per week, or at least 75 minutes ofvigorous physical activity per week, independently from the number of weekly sessions); and Watchingtelevision (TV) three or more hours per day (\% of individuals who watch TV three or more hours per day).

e) Alcohol abuse (four [women]/five [men] or more doses of alcoholon a single occasion within the past 30 days, considering as one dose of alcohol: one measure of any distilled beverage, one beer can or one glass of wine); and Driving after drinking alcohol (\% of adults who reported driving after having drunk alcohol).

f) Reported morbidity (report of previously diagnosed arterial hypertension or diabetes).

g) Self-assessed state of health (\% of adults who assessed their state of health as poor)

h) Performance of cancer screening tests by women: mammogram (women 50 to 69 years old) and Papanicolaou (Pap) testing (women 25 to 59 years old).
In all of the indicators, the denominator was the total number of interviewed adults, except for the gender- or age-specific indicators.

\section{Time series analysis}

The first step of the calculation method was the construction of a time series $\left(Z_{t}\right)$ for each indicator using secondary data. The estimates of risk and protective factors corresponding to the period from 2008 to 2013 were extracted from the Vigitel databases.

The second step wastime series $\left(\mathrm{Z}_{\mathrm{t}}\right)$ modeling to establish whether atrend wassignificant. In this study, modeling was performed by means of simple linear regression according to the equation $Z_{t}=\alpha+\beta^{*} t+a_{t}$, where $Z_{t}$ is the prevalence at time $\mathrm{t} ; \alpha$, the intercept; $\beta$, the regression coefficient or slope, with $t$ ranging from 2008 to 2012; and $a_{p}$ the residuals(random error). A positive regression coefficient indicates an increasing tendency, while a negative coefficient indicates a falling tendency. The following tests were used to check the model goodness-of-fit: analysis of variance (ANOVA), which indicates whether the function fit by the linear model $\left(Z_{t}\right.$ $=\alpha+\beta^{*} t+a$ ) decreases the residual variance compared to the simple model $\left(Z_{t}=\mu+a_{t}\right)$ we used to test hypothesis: $H_{0}: \beta=0$ at $5 \%$ significance; coefficient of determination $\left(\frac{S Q_{\text {regression }}}{S Q_{\text {tota }}}\right)$, which measures the strength of the association between indicator and time; residual analysis, calculated as the difference between actual $\left(Z_{t}\right)$ and adjusted $\left(\hat{Z}_{t}\right)$ prevalence, which indicates the quality of model-fitting: standardized residuals within the range - 2 to 2 indicate a lack of atypical values that might lead to over- or underestimating a trend; and the p-value of coefficients $\alpha$ (intercept or intersection) and $\beta$ (regression coefficient). The significance level was set as less than $5 \%$ in ANOVA and $\mathrm{R}^{2}$ equal to or higher than $70 \%$. The assumption underlying time series analysis was that what happened in the past will repeat in the future ${ }^{14}$.

The Vigitel survey was approved by the National Commission of Human Research Ethics, Health Ministry. Written informed consent was replaced by verbal consent manifested by interviewees upon being contacted by phone. 


\section{Results}

The prevalence of protective factors was generally higher and the frequency of risk factors lower among the population with private health insurance. The lower prevalence of smokers, higher prevalence of fruit, legume and vegetable (FLV) intake, lower frequency of fat meat intake and lower frequency of soft drink intake stand out. Half of the population with or without private health insurance was overweight, and the prevalence of obesity was high in both groups. The prevalence of alcohol abuse was high in both groups, while drinking and driving was more common in the group with private health insurance. The insured women performed cancer-screening tests (mammogram and Pap testing) more often. Self-assessment of the state of health as poor was three times more frequent among the population without private health insurance. Although the frequency of free-time physical activity was higher in the insured population, it exhibited increasing trends in both groups (Table 1). The population with private health insurance exhibited the lowest prevalence of smokers throughout the study period. The prevalence of smokers in that group decreased $0.72 \%$ per year, i.e., from $12.4 \%$ to $8.6 \%$ in 2013 (Table 2).

The frequency of individuals who were overweight among the group with private health insurance increased $1.03 \%$ per year, i.e., from $45.8 \%$ (2006) to $49.6 \%$ (2013).

Similarly, the prevalence of obesity in that group increased $0.74 \%$ per year, i.e., from $12.9 \%$ (2008) to $16.2 \%$ (2013). It is worth noting that this prevalence rate remained stable from 2012 to 2013.

Relative to the dietary intake, the consumption of beans and soft drinks remained stable, while the intake of recommended FLV increased from $24.9 \%$ (2008) to $28.3 \%$ (2013), i.e., $0.83 \%$ per year. Consumption of whole milk decreased from $52.1 \%$ (2008) to $49.1 \%$ (2013), i.e., $-0.94 \%$ per year. The remaining variables representing dietary intake remained stable throughout the investigated period.

Free-time physical activity increased $1.17 \%$ per year, i.e., from $35.1 \%$ (2008) to $39.3 \%$ (2013) in the group with private health insurance (Table 2).

The frequency of mammograms was stable among the insured population. The remaining investigated trends were also stable in this group: reported morbidity, self-assessed state of health,
TV watching habit, alcohol abuse and drinking and driving (Table 2).

Among the population without private health insurance, the prevalence of tobacco use decreased $0.67 \%$ per year, i.e., from $16.8 \%$ to $13.7 \%$ in 2013 (Table 3).

In this group, the frequency of overweight increased $1.53 \%$ per year, i.e., from $44.0 \%$ (2008) to $51.7 \%$ (2013). It is worth noting that the percentage variation remained stable from 2012 to 2013.

Obesity exhibited a similar pattern, with a $0.95 \%$ increase per year, i.e., from $14.2 \%$ to 18.5\% (2013), but leveled off from 2012 to 2013.

Relative to dietary intake, the consumption of beans, soft drinks, meat with visible fat and whole milk remained stable. The frequency of recommended FLV intake increased from 15.9\% (2008) to $19.3 \%$ (2013), i.e., $0.72 \%$ per year.

Free-time physical activity increased $1.01 \%$ per year in the group without private health insurance, i.e., from $25.3 \%$ (2009) to $28.8 \%$ (2013) (Table 3).

The frequency of mammograms increased in this group from $59.3 \%$ to $70.9 \%$, i.e., $2.4 \%$ per year; this indicator had the greatest growth throughout the investigated period. In contrast, mammogram frequency remained stable among the women with private health insurance $(0.28 \%$ per year; $\mathrm{p}=0.30$ ). The frequency of Pap testing remained stable throughout the investigated period.

The remaining investigated variables were stable: reported morbidity, self-assessed state of health, TV-watching habits, alcohol abuse and drinking and driving.

\section{Discussion}

The prevalence of protective factors was generally higher and the frequency of risk factors lower among the population with private health insurance. The results indicate an improvement of the trends exhibited by the protective factors freetime physical activity, increased FLV intake and reduced prevalence of tobacco use. The mammogram coverage exhibited a remarkable increase in the group of women without private health insurance only. Overweight and obesity increased in both groups until leveling off from 2012 to 2013. The consumption of milk decreased in the population with private health insurance.

The higher prevalence of risk factors among populations without health insurance coverage was previously described in a study conducted 
Table 1. List of (95\%) confidence intervals for the frequencies of indicators and prevalence ratios per year, stratified per health insurance coverage. Set of 26 state capitals and the Federal District, 2008-2013.

\begin{tabular}{|c|c|c|c|c|c|c|c|c|c|c|}
\hline \multirow{4}{*}{ Indicator $^{*}$} & \multirow{4}{*}{ Ano } & \multicolumn{6}{|c|}{ Health insurance coverage } & \multirow{4}{*}{$\mathbf{P R}^{* *}$} & & \\
\hline & & \multicolumn{3}{|c|}{ Yes } & \multicolumn{3}{|c|}{ No } & & \multirow{2}{*}{\multicolumn{2}{|c|}{$(95 \%) \mathrm{CI}$}} \\
\hline & & \multirow[t]{2}{*}{ Prev. } & \multicolumn{2}{|c|}{$(95 \%) \mathrm{CI}$} & \multirow[t]{2}{*}{ Prev. } & \multicolumn{2}{|c|}{$(95 \%) \mathrm{CI}$} & & & \\
\hline & & & & UL & & $\mathbf{L L}$ & UL & & LL & UL \\
\hline \multirow[t]{6}{*}{ Smokers } & 2008 & 12.39 & 11.51 & 13.27 & 16.80 & 15.81 & 17.80 & 0.84 & 0.76 & 0.93 \\
\hline & 2009 & 11.20 & 10.40 & 12.01 & 17.03 & 15.99 & 18.08 & 0.74 & 0.67 & 0.82 \\
\hline & 2010 & 10.94 & 10.09 & 11.79 & 16.79 & 15.75 & 17.84 & 0.74 & 0.66 & 0.83 \\
\hline & 2011 & 10.06 & 9.28 & 10.83 & 16.36 & 15.36 & 17.35 & 0.70 & 0.63 & 0.77 \\
\hline & 2012 & 9.37 & 8.57 & 10.17 & 14.54 & 13.49 & 15.60 & 0.72 & 0.64 & 0.80 \\
\hline & 2013 & 8.61 & 7.86 & 9.36 & 13.66 & 12.70 & 14.62 & 0.72 & 0.64 & 0.82 \\
\hline \multirow[t]{6}{*}{ Overweight ${ }^{* * *}$} & 2008 & 45.81 & 44.61 & 47.02 & 44.03 & 42.84 & 45.22 & 1.05 & 1.01 & 1.10 \\
\hline & 2009 & 45.62 & 44.44 & 46.80 & 46.26 & 44.97 & 47.56 & 1.02 & 0.98 & 1.06 \\
\hline & 2010 & 48.62 & 47.42 & 49.81 & 47.86 & 46.54 & 49.18 & 1.04 & 1.00 & 1.08 \\
\hline & 2011 & 49.35 & 48.17 & 50.52 & 48.40 & 47.20 & 49.59 & 1.02 & 0.98 & 1.06 \\
\hline & 2012 & 50.96 & 49.66 & 52.26 & 51.08 & 49.76 & 52.41 & 1.00 & 0.97 & 1.04 \\
\hline & 2013 & 49.66 & 48.46 & 50.87 & 51.74 & 50.50 & 52.98 & 0.97 & 0.94 & 1.01 \\
\hline \multirow{6}{*}{ Obesity $^{* * *}$} & 2008 & 12.93 & 12.09 & 13.76 & 14.24 & 13.39 & 15.08 & 0.97 & 0.88 & 1.06 \\
\hline & 2009 & 13.72 & 12.90 & 14.55 & 14.88 & 13.96 & 15.80 & 1.01 & 0.92 & 1.10 \\
\hline & 2010 & 14.33 & 13.53 & 15.12 & 15.72 & 14.84 & 16.61 & 0.95 & 0.87 & 1.03 \\
\hline & 2011 & 15.05 & 14.23 & 15.87 & 16.96 & 16.09 & 17.83 & 0.92 & 0.85 & 1.00 \\
\hline & 2012 & 16.24 & 15.29 & 17.19 & 18.45 & 17.42 & 19.47 & 0.94 & 0.86 & 1.02 \\
\hline & 2013 & 16.42 & 15.55 & 17.30 & 18.53 & 17.57 & 19.49 & 0.93 & 0.85 & 1.00 \\
\hline \multirow{6}{*}{$\begin{array}{l}\text { Regular bean intake } \\
\text { ( } 5 \text { or more times per } \\
\text { week) }\end{array}$} & 2008 & 59.77 & 58.61 & 60.93 & 70.50 & 69.48 & 71.51 & 0.93 & 0.91 & 0.96 \\
\hline & 2009 & 59.82 & 58.69 & 60.96 & 69.40 & 68.28 & 70.52 & 0.94 & 0.92 & 0.97 \\
\hline & 2010 & 61.45 & 60.31 & 62.60 & 69.21 & 68.09 & 70.34 & 0.97 & 0.95 & 1.00 \\
\hline & 2011 & 63.82 & 62.73 & 64.92 & 70.99 & 69.98 & 72.01 & 0.97 & 0.95 & 0.99 \\
\hline & 2012 & 63.35 & 62.13 & 64.56 & 71.32 & 70.22 & 72.41 & 0.95 & 0.92 & 0.97 \\
\hline & 2013 & 62.54 & 61.40 & 63.69 & 70.84 & 69.79 & 71.89 & 0.94 & 0.91 & 0.96 \\
\hline \multirow{6}{*}{$\begin{array}{l}\text { Regular fruit and } \\
\text { vegetable intake }\end{array}$} & 2008 & 40.39 & 39.22 & 41.55 & 26.69 & 25.66 & 27.73 & 1.28 & 1.22 & 1.35 \\
\hline & 2009 & 39.22 & 38.08 & 40.35 & 25.93 & 24.82 & 27.03 & 1.27 & 1.21 & 1.34 \\
\hline & 2010 & 38.94 & 37.80 & 40.08 & 26.11 & 24.97 & 27.25 & 1.23 & 1.16 & 1.30 \\
\hline & 2011 & 39.98 & 38.85 & 41.11 & 27.98 & 26.92 & 29.05 & 1.22 & 1.16 & 1.28 \\
\hline & 2012 & 41.71 & 40.46 & 42.97 & 27.05 & 25.93 & 28.17 & 1.32 & 1.25 & 1.40 \\
\hline & 2013 & 43.13 & 41.96 & 44.31 & 29.57 & 28.48 & 30.65 & 1.27 & 1.21 & 1.33 \\
\hline \multirow{6}{*}{$\begin{array}{l}\text { Recommended fruit } \\
\text { and vegetable intake }\end{array}$} & 2008 & 24.90 & 23.88 & 25.91 & 15.90 & 15.03 & 16.77 & 1.29 & 1.20 & 1.39 \\
\hline & 2009 & 24.93 & 23.93 & 25.92 & 15.92 & 14.98 & 16.86 & 1.28 & 1.19 & 1.38 \\
\hline & 2010 & 23.93 & 22.94 & 24.92 & 15.74 & 14.78 & 16.69 & 1.21 & 1.12 & 1.30 \\
\hline & 2011 & 25.91 & 24.90 & 26.91 & 18.38 & 17.45 & 19.32 & 1.18 & 1.10 & 1.26 \\
\hline & 2012 & 28.28 & 27.13 & 29.43 & 17.74 & 16.78 & 18.70 & 1.35 & 1.25 & 1.45 \\
\hline & 2013 & 28.33 & 27.26 & 29.39 & 19.33 & 18.38 & 20.28 & 1.26 & 1.18 & 1.35 \\
\hline \multirow[t]{6}{*}{ Fatty meat intake } & 2008 & 28.00 & 26.88 & 29.12 & 35.25 & 34.06 & 36.44 & 0.89 & 0.84 & 0.94 \\
\hline & 2009 & 28.38 & 27.26 & 29.50 & 35.56 & 34.29 & 36.82 & 0.86 & 0.81 & 0.91 \\
\hline & 2010 & 28.61 & 27.51 & 29.72 & 36.64 & 35.34 & 37.94 & 0.86 & 0.81 & 0.90 \\
\hline & 2011 & 29.71 & 28.61 & 30.81 & 34.91 & 33.73 & 36.08 & 0.94 & 0.89 & 0.99 \\
\hline & 2012 & 27.89 & 26.70 & 29.08 & 34.85 & 33.54 & 36.15 & 0.86 & 0.81 & 0.91 \\
\hline & 2013 & 27.95 & 26.83 & 29.08 & 33.66 & 32.45 & 34.87 & 0.88 & 0.83 & 0.93 \\
\hline Whole milk intake & 2008 & 52.13 & 50.93 & 53.34 & 59.85 & 58.67 & 61.04 & 0.91 & 0.88 & 0.94 \\
\hline & 2009 & 53.73 & 52.55 & 54.92 & 61.47 & 60.23 & 62.72 & 0.93 & 0.90 & 0.96 \\
\hline & 2010 & 51.41 & 50.22 & 52.60 & 59.75 & 58.47 & 61.03 & 0.91 & 0.88 & 0.94 \\
\hline & 2011 & 51.00 & 49.83 & 52.18 & 60.34 & 59.18 & 61.51 & 0.88 & 0.85 & 0.91 \\
\hline & 2012 & 47.96 & 46.67 & 49.26 & 59.15 & 57.85 & 60.44 & 0.84 & 0.81 & 0.87 \\
\hline & 2013 & 49.09 & 47.88 & 50.29 & 57.46 & 56.24 & 58.68 & 0.88 & 0.85 & 0.91 \\
\hline
\end{tabular}


Tabela 1. continuation

\begin{tabular}{|c|c|c|c|c|c|c|c|c|c|c|}
\hline \multirow{4}{*}{ Indicator $^{*}$} & \multirow{4}{*}{ Ano } & \multicolumn{6}{|c|}{ Health insurance coverage } & \multirow{4}{*}{$\mathbf{P R}^{* *}$} & & \\
\hline & & \multicolumn{3}{|c|}{ Yes } & \multicolumn{3}{|c|}{ No } & & \multirow{2}{*}{\multicolumn{2}{|c|}{$(95 \%) \mathrm{CI}$}} \\
\hline & & \multirow[t]{2}{*}{ Prev. } & \multicolumn{2}{|c|}{$(95 \%) \mathrm{CI}$} & \multirow[t]{2}{*}{ Prev. } & \multicolumn{2}{|c|}{$(95 \%) \mathrm{CI}$} & & & \\
\hline & & & LL & UL & & LL & UL & & $\mathbf{L L}$ & UL \\
\hline \multirow{6}{*}{$\begin{array}{l}\text { Regular soft drink } \\
\text { intake ( } 5 \text { times or } \\
\text { more per week) }\end{array}$} & 2008 & 26.06 & 24.93 & 27.20 & 26.71 & 25.56 & 27.85 & 1.02 & 0.96 & 1.09 \\
\hline & 2009 & 25.75 & 24.64 & 26.85 & 26.17 & 24.96 & 27.37 & 1.01 & 0.94 & 1.08 \\
\hline & 2010 & 26.58 & 25.44 & 27.71 & 26.98 & 25.81 & 28.15 & 1.00 & 0.93 & 1.06 \\
\hline & 2011 & 25.85 & 24.77 & 26.94 & 29.00 & 27.85 & 30.14 & 0.93 & 0.87 & 0.98 \\
\hline & 2012 & 24.03 & 22.84 & 25.22 & 27.69 & 26.44 & 28.94 & 0.91 & 0.85 & 0.98 \\
\hline & 2013 & 21.76 & 20.67 & 22.85 & 24.63 & 23.48 & 25.78 & 0.95 & 0.89 & 1.02 \\
\hline \multirow[t]{6}{*}{ Alcohol abuse } & 2008 & 17.09 & 16.17 & 18.02 & 17.33 & 16.41 & 18.25 & 0.98 & 0.90 & 1.06 \\
\hline & 2009 & 18.82 & 17.89 & 19.75 & 18.13 & 17.11 & 19.15 & 0.96 & 0.89 & 1.04 \\
\hline & 2010 & 19.36 & 18.40 & 20.32 & 16.96 & 16.00 & 17.92 & 1.06 & 0.98 & 1.15 \\
\hline & 2011 & 16.56 & 15.66 & 17.45 & 16.51 & 15.60 & 17.42 & 0.93 & 0.86 & 1.00 \\
\hline & 2012 & 19.03 & 17.97 & 20.10 & 17.89 & 16.81 & 18.96 & 1.02 & 0.93 & 1.10 \\
\hline & 2013 & 16.77 & 15.83 & 17.70 & 16.02 & 15.07 & 16.96 & 0.97 & 0.89 & 1.05 \\
\hline \multirow{6}{*}{$\begin{array}{l}\text { Poor self-assessed } \\
\text { health }\end{array}$} & 2008 & 3.46 & 3.03 & 3.89 & 5.52 & 4.97 & 6.06 & 0.79 & 0.67 & 0.94 \\
\hline & 2009 & 3.10 & 2.67 & 3.52 & 6.02 & 5.44 & 6.61 & 0.66 & 0.55 & 0.80 \\
\hline & 2010 & 3.11 & 2.66 & 3.55 & 5.66 & 5.11 & 6.20 & 0.73 & 0.60 & 0.88 \\
\hline & 2011 & 3.19 & 2.78 & 3.59 & 5.76 & 5.25 & 6.28 & 0.73 & 0.62 & 0.86 \\
\hline & 2012 & 2.81 & 2.43 & 3.19 & 7.06 & 6.29 & 7.83 & 0.52 & 0.44 & 0.62 \\
\hline & 2013 & 3.18 & 2.78 & 3.58 & 6.44 & 5.82 & 7.05 & 0.62 & 0.53 & 0.73 \\
\hline \multirow{6}{*}{$\begin{array}{l}\text { Arterial } \\
\text { hypertension }\end{array}$} & 2008 & 23.77 & 22.75 & 24.78 & 26.63 & 25.54 & 27.72 & 0.90 & 0.85 & 0.95 \\
\hline & 2009 & 22.77 & 21.81 & 23.73 & 27.91 & 26.72 & 29.10 & 0.86 & 0.82 & 0.91 \\
\hline & 2010 & 22.52 & 21.59 & 23.45 & 25.79 & 24.67 & 26.91 & 0.91 & 0.86 & 0.97 \\
\hline & 2011 & 22.79 & 21.87 & 23.71 & 25.69 & 24.67 & 26.71 & 0.88 & 0.83 & 0.93 \\
\hline & 2012 & 23.05 & 22.02 & 24.08 & 25.47 & 24.37 & 26.57 & 0.94 & 0.89 & 1.00 \\
\hline & 2013 & 22.79 & 21.85 & 23.74 & 25.31 & 24.28 & 26.34 & 0.92 & 0.87 & 0.98 \\
\hline \multirow[t]{6}{*}{ Diabetes } & 2008 & 6.03 & 5.47 & 6.60 & 6.37 & 5.76 & 6.98 & 0.99 & 0.86 & 1.13 \\
\hline & 2009 & 5.96 & 5.42 & 6.49 & 6.66 & 5.94 & 7.39 & 0.95 & 0.83 & 1.09 \\
\hline & 2010 & 6.51 & 5.98 & 7.05 & 7.02 & 6.39 & 7.64 & 0.94 & 0.83 & 1.06 \\
\hline & 2011 & 6.29 & 5.73 & 6.85 & 6.27 & 5.73 & 6.80 & 1.01 & 0.89 & 1.15 \\
\hline & 2012 & 6.78 & 6.18 & 7.38 & 7.91 & 7.22 & 8.61 & 0.87 & 0.77 & 0.99 \\
\hline & 2013 & 6.57 & 6.02 & 7.12 & 7.14 & 6.53 & 7.76 & 0.99 & 0.88 & 1.11 \\
\hline \multirow{5}{*}{$\begin{array}{l}\text { Watch TV } 3 \text { hours } \\
\text { per day }\end{array}$} & 2009 & 22.22 & 21.23 & 3.21 & 27.99 & 26.80 & 29.17 & 0.87 & 0.82 & 0.93 \\
\hline & 2010 & 25.28 & 24.24 & 26.32 & 28.96 & 27.74 & 30.18 & 0.89 & 0.84 & 0.95 \\
\hline & 2011 & 24.48 & 23.47 & 25.49 & 27.25 & 26.18 & 28.33 & 0.93 & 0.88 & 0.99 \\
\hline & 2012 & 24.33 & 23.23 & 25.43 & 28.32 & 27.08 & 29.56 & 0.90 & 0.84 & 0.96 \\
\hline & 2013 & 26.01 & 24.96 & 27.06 & 30.92 & 29.75 & 32.09 & 0.89 & 0.84 & 0.95 \\
\hline
\end{tabular}

it continues

in the United States (USA) ${ }^{7,8}$, which showed that such populations exhibit higher risk of NCDs and poorer access to healthcare services ${ }^{7,8}$. Worse results were reported for populations without health insurance coverage, youths, non-whites, autonomous workers, unemployed people, individuals with low-paying jobs, and low-income populations $s^{7,8,15,16}$. The frequencies of screening tests, such as mammograms, colonoscopy and Pap testing, are higher in populations with health insurance coverage ${ }^{7}$.
One study conducted in the metropolitan area of Belo Horizonte, Brazil ${ }^{9}$ found that individuals with health insurance coverage exhibited healthier habits, such as less tobacco use and more free-time physical activity, consumed five or more daily FLV portions, and performed cancer screening tests more often'.

In the USA and Brazil, the population with health insurance coverage typically has more schooling and income, which is usually associated with wider access to goods and services ${ }^{9,10,15-18}$. 
Tabela 1. continuation

\begin{tabular}{|c|c|c|c|c|c|c|c|c|c|c|}
\hline \multirow{4}{*}{ Indicator $^{*}$} & \multirow{4}{*}{ Ano } & \multicolumn{6}{|c|}{ Health insurance coverage } & \multirow{4}{*}{$\mathbf{P R}^{* *}$} & \multirow{3}{*}{\multicolumn{2}{|c|}{$(95 \%) \mathrm{CI}$}} \\
\hline & & \multicolumn{3}{|c|}{ Yes } & \multicolumn{3}{|c|}{ No } & & & \\
\hline & & \multirow[t]{2}{*}{ Prev. } & \multicolumn{2}{|c|}{$(95 \%) \mathrm{CI}$} & \multirow[t]{2}{*}{ Prev. } & \multicolumn{2}{|c|}{$(95 \%) \mathrm{CI}$} & & & \\
\hline & & & & UL & & LL & UL & & LL & UL \\
\hline \multirow{6}{*}{$\begin{array}{l}\text { Drinking and } \\
\text { driving }\end{array}$} & 2008 & 1.90 & 1.56 & 2.24 & 1.30 & 1.04 & 1.56 & 1.25 & 0.84 & 1.87 \\
\hline & 2009 & 12.11 & 1.80 & 2.41 & 1.45 & 1.15 & 1.76 & 1.21 & 0.95 & 1.54 \\
\hline & 2010 & 2.10 & 1.81 & 2.38 & 1.14 & 0.93 & 1.34 & 1.45 & 1.14 & 1.84 \\
\hline & 2011 & 2.07 & 1.77 & 2.38 & 1.03 & 0.85 & 1.22 & 1.59 & 1.27 & 1.99 \\
\hline & 2012 & 2.07 & 1.69 & 2.45 & 1.27 & 1.01 & 1.52 & 1.32 & 0.96 & 1.81 \\
\hline & 2013 & 1.23 & 1.01 & 1.45 & 1.02 & 0.75 & 1.28 & 1.01 & 0.71 & 1.42 \\
\hline \multirow{6}{*}{$\begin{array}{l}\text { Mammogram in the } \\
\text { past } 2 \text { years }\end{array}$} & 2008 & 84.94 & 82.75 & 87.13 & 59.27 & 56.25 & 62.29 & 1.39 & 1.31 & 1.48 \\
\hline & 2009 & 84.95 & 83.06 & 86.84 & 61.19 & 58.33 & 64.06 & 1.32 & 1.25 & 1.40 \\
\hline & 2010 & 85.68 & 83.81 & 87.55 & 61.53 & 58.64 & 64.42 & 1.35 & 1.28 & 1.43 \\
\hline & 2011 & 85.70 & 83.59 & 87.82 & 63.43 & 60.73 & 66.13 & 1.28 & 1.22 & 1.35 \\
\hline & 2012 & 86.73 & 84.49 & 88.98 & 69.25 & 66.60 & 71.91 & 1.20 & 1.14 & 1.26 \\
\hline & 2013 & 85.82 & 83.75 & 87.89 & 70.86 & 68.44 & 73.28 & 1.17 & 1.12 & 1.23 \\
\hline \multirow{6}{*}{$\begin{array}{l}\text { Pap test in the past } \\
3 \text { years }\end{array}$} & 2008 & 90.44 & 89.35 & 91.52 & 77.92 & 76.47 & 79.37 & 1.12 & 1.09 & 1.15 \\
\hline & 2009 & 88.79 & 87.74 & 89.85 & 76.31 & 74.83 & 77.79 & 1.13 & 1.10 & 1.15 \\
\hline & 2010 & 89.83 & 88.73 & 90.93 & 76.02 & 74.05 & 77.99 & 1.15 & 1.12 & 1.18 \\
\hline & 2011 & 87.88 & 86.71 & 89.06 & 76.88 & 75.43 & 78.34 & 1.10 & 1.07 & 1.13 \\
\hline & 2012 & 89.03 & 87.94 & 90.12 & 76.33 & 74.76 & 77.90 & 1.13 & 1.10 & 1.16 \\
\hline & 2013 & 88.99 & 87.91 & 90.07 & 77.62 & 76.13 & 79.10 & 1.12 & 1.09 & 1.14 \\
\hline \multirow{5}{*}{$\begin{array}{l}\text { Sufficient free-time } \\
\text { physical activity }\end{array}$} & 2009 & 35.10 & 33.98 & 36.22 & 25.25 & 24.16 & 26.34 & 1.19 & 1.13 & 1.26 \\
\hline & 2010 & 36.11 & 34.96 & 37.26 & 24.89 & 23.76 & 26.03 & 1.26 & 1.19 & 1.34 \\
\hline & 2011 & 37.64 & 36.50 & 38.77 & 26.20 & 25.16 & 27.23 & 1.24 & 1.18 & 1.31 \\
\hline & 2012 & 39.49 & 38.23 & 40.76 & 27.98 & 26.81 & 29.15 & 1.25 & 1.18 & 1.32 \\
\hline & 2013 & 39.27 & 38.11 & 40.44 & 28.77 & 27.68 & 29.87 & 1.19 & 1.14 & 1.25 \\
\hline
\end{tabular}

"Weighted percentage to adjust the sociodemographic distribution of the Vigitel sample to the projected distribution of the adult population from the same city per study year (see Methodological Features 2012). ${ }^{* *}$ Imputed missing data. ${ }^{* *}$ Prevalence ratios adjusted for age, gender and level of schooling.

There are also historical inequalities in the installed capacity and access to services and equipment between different regions, urban and rural areas, types of services and human resources ${ }^{6,18,19}$.Such inequalities have been attenuated by the Unified Health System (Sistema Único de Saúde - SUS), which grants universal access to healthcare.

The Health Ministry recommends Pap testing every three years for women of reproductive age ${ }^{20}$ and mammograms every two years for women 50 to 69 years old, based on international evidence on the beneficial impact of screening on breast cancer mortality in women within that age range ${ }^{21}$.

Vigitel data showed that the coverage of cancer screening tests, such as mammograms and Pap testing, is wider among health insured women, which might be accounted for by the greater access to services among that population ${ }^{7,8,10}$.
Studies based on the Sanitary Medical Care Survey (Pesquisa sobre Assistência Médica Sanitária - AMS) showed that the numbers of hospital beds and equipment such as mammography devices are larger in the private healthcare setting $^{22}$. This situation is gradually changing as a function of the investment made by the Health Ministry on a program that prioritizes the control of breast and cervical cancer ${ }^{23,24}$. The present study showed that over a short period of time, the access to mammograms improved much faster in the SUS. In this regard, it is worth noting that the coverage of mammograms among the population without health insurance reached $75 \%$ of the goal established for 2022 in the Plan for Combat of Chronic Diseases ${ }^{3,25}$; that goal has already been accomplished among the population with private health insurance.

Although the frequency of Pap testing was also higher among women with private health 
Table 2. Analysis of the time series trends for indicators corresponding to the population with private health insurance. Set of 26 state capitals and the Federal District, 2008-2013.

\begin{tabular}{|c|c|c|c|c|c|c|c|c|c|c|}
\hline Indicator $^{*}$ & 2008 & 2009 & 2010 & 2011 & 2012 & 2013 & $\begin{array}{l}\text { Regression } \\
\text { coefficient }\end{array}$ & $\begin{array}{c}\text { p- } \\
\text { value }\end{array}$ & $\mathbf{R}^{2}$ & Trend \\
\hline Smokers & 12.39 & 11.20 & 10.94 & 10.06 & 9.37 & 8.61 & -0.72 & 0.00 & 0.98 & Decrease \\
\hline Overweight $^{* *}$ & 45.81 & 45.62 & 48.62 & 49.35 & 50.96 & 49.66 & 1.03 & 0.02 & 0.79 & Increase \\
\hline Obesity $^{* *}$ & 12.93 & 13.72 & 14.33 & 15.05 & 16.24 & 16.42 & 0.74 & 0.00 & 0.98 & Increase \\
\hline Bean intake & 59.77 & 59.82 & 61.45 & 63.82 & 63.35 & 62.54 & 0.77 & 0.05 & 0.68 & - \\
\hline Regular FLV & 40.39 & 39.22 & 38.94 & 39.98 & 41.71 & 43.13 & 0.64 & 0.09 & 0.56 & - \\
\hline Recommended FLV & 24.90 & 24.93 & 23.93 & 25.91 & 28.28 & 28.33 & 0.83 & 0.04 & 0.71 & Increase \\
\hline Meat with visible fat & 28.00 & 28.38 & 28.61 & 29.71 & 27.89 & 27.95 & -0.02 & 0.93 & 0.00 & - \\
\hline Whole milk & 52.13 & 53.73 & 51.41 & 51.00 & 47.96 & 49.09 & -0.94 & 0.03 & 0.71 & Decrease \\
\hline Alcohol abuse & 17.09 & 18.82 & 19.36 & 16.56 & 19.03 & 16.77 & -0.11 & 0.76 & 0.03 & - \\
\hline Poor self-assessed health & 3.46 & 3.10 & 3.11 & 3.19 & 2.81 & 3.18 & -0.06 & 0.25 & 0.31 & - \\
\hline Reported hypertension & 23.77 & 22.77 & 22.52 & 22.79 & 23.05 & 22.79 & -0.11 & 0.36 & 0.21 & - \\
\hline Reported diabetes & 6.03 & 5.96 & 6.51 & 6.29 & 6.78 & 6.57 & 0.14 & 0.05 & 0.67 & - \\
\hline Total soft drinks & 26.06 & 25.75 & 26.58 & 25.85 & 24.03 & 21.76 & -0.78 & 0.05 & 0.66 & - \\
\hline Watch TV $3 \mathrm{~h}$ per day & 23.83 & 22.22 & 25.28 & 24.48 & 24.33 & 26.01 & 0.66 & 0.16 & 0.54 & - \\
\hline Drinking and driving & 1.90 & 2.11 & 2.10 & 2.07 & 2.07 & 1.23 & -0.10 & 0.26 & 0.30 & - \\
\hline Mammogram in the past 2 years & 84.94 & 84.95 & 85.68 & 85.70 & 86.73 & 85.82 & 0.28 & 0.06 & 0.62 & - \\
\hline Pap test in the past 3 years & 90.44 & 89.04 & 89.83 & 87.88 & 89.03 & 88.99 & -0.24 & 0.30 & 0.26 & - \\
\hline Sufficient free-time physical activity & & 35.10 & 36.11 & 37.64 & 39.49 & 39.27 & 1.17 & 0.01 & 0.93 & Increase \\
\hline
\end{tabular}

"Weighted percentage to adjust the sociodemographic distribution of the Vigitel sample to the projected distribution of the adult population from the same city per study year (see Methodological Features 2012). ** Imputed missing data.

Table 3. Analysis of the time series trendsfor indicators corresponding to the population without private health insurance. Set of 26 state capitals and the Federal District, 2008-2013.

\begin{tabular}{|c|c|c|c|c|c|c|c|c|c|c|}
\hline Indicator $^{*}$ & 2008 & 2009 & 2010 & 2011 & 2012 & 2013 & $\begin{array}{l}\text { Regression } \\
\text { coefficient }\end{array}$ & $\begin{array}{c}\text { p- } \\
\text { value }\end{array}$ & $\mathbf{R}^{2}$ & Trend \\
\hline Smokers & 16.80 & 17.03 & 16.79 & 16.36 & 14.54 & 13.66 & -0.67 & 0.02 & 0.80 & Decrease \\
\hline Overweight $^{* *}$ & 44.03 & 46.26 & 47.86 & 48.40 & 51.08 & 51.74 & 1.53 & 0.00 & 0.97 & Increase \\
\hline Obesity $^{* *}$ & 14.24 & 14.88 & 15.72 & 16.96 & 18.45 & 18.53 & 0.95 & 0.00 & 0.97 & Increase \\
\hline Bean intake & 70.50 & 69.40 & 69.21 & 70.99 & 71.32 & 70.84 & 0.26 & 0.24 & 0.32 & - \\
\hline Regular FLV & 26.69 & 25.93 & 26.11 & 27.98 & 27.05 & 29.57 & 0.56 & 0.07 & 0.59 & - \\
\hline Recommended FLV & 15.90 & 15.92 & 15.74 & 18.38 & 17.74 & 19.33 & 0.72 & 0.02 & 0.78 & Increase \\
\hline Meat with visible fat & 35.25 & 35.56 & 36.64 & 34.91 & 34.85 & 33.66 & -0.34 & 0.17 & 0.42 & - \\
\hline Whole milk & 59.85 & 61.47 & 59.75 & 60.34 & 59.15 & 57.46 & -0.52 & 0.10 & 0.54 & - \\
\hline Alcohol abuse & 17.33 & 18.13 & 16.96 & 16.51 & 17.89 & 16.02 & -0.22 & 0.30 & 0.26 & - \\
\hline Poor self-assessed health & 5.52 & 6.02 & 5.66 & 5.76 & 7.06 & 6.44 & 0.22 & 0.11 & 0.52 & - \\
\hline Reported hypertension & 26.63 & 27.91 & 25.79 & 25.69 & 25.47 & 25.31 & -0.40 & 0.08 & 0.58 & - \\
\hline Reported diabetes & 6.37 & 6.66 & 7.02 & 6.27 & 7.91 & 7.14 & 0.20 & 0.20 & 0.37 & - \\
\hline Total soft drinks & 26.71 & 26.17 & 26.98 & 29.00 & 27.69 & 24.63 & -0.11 & 0.79 & 0.02 & - \\
\hline Watch TV 3 h per day & 27.88 & 27.99 & 28.96 & 27.25 & 28.32 & 30.92 & 0.52 & 0.29 & 0.35 & - \\
\hline Drinking and driving & 1.30 & 1.45 & 1.14 & 1.03 & 1.27 & 1.02 & -0.06 & 0.16 & 0.43 & - \\
\hline Mammogram in the past 2 years & 59.27 & 61.19 & 61.53 & 63.43 & 69.25 & 70.86 & 2.40 & 0.00 & 0.91 & Increase \\
\hline Pap test in the past 3 years & 77.92 & 76.51 & 76.02 & 76.88 & 76.33 & 77.62 & -0.02 & 0.94 & 0.00 & - \\
\hline Sufficient free-time physical activity & - & 25.25 & 24.89 & 26.20 & 27.98 & 28.77 & 1.01 & 0.02 & 0.89 & Increase \\
\hline
\end{tabular}

*Weighted percentage to adjust the sociodemographic distribution of the Vigitel sample to the projected distribution of the adult population from the same city per study year (see Methodological Features 2012). "* Imputed missingdata. 
insurance, the differences are smaller among uninsured women, as Pap testing is performed at the primary care level by the SUS Family Health Program, which has wide coverage, particularly among the SUS-dependent, low-income population $^{6}$. The target established for the Plan for Combat of Chronic Diseases is to achieve 85\% average coverage of Pap testing by 2022, which has already been accomplished among the population with private health insurance and is very close to being met among the population with only SUS care $(76.3 \%)^{3,25}$.

In 2008, the global prevalence of diabetes was estimated to be $10 \%$ and that of arterial hypertension to range from 25 to $40 \%{ }^{1}$. As Vigitel considers self-reported morbidity, the prevalence of some diseases might be underestimated because of previously established medical diagnoses, thus implying access to services. Such measurements might be advantageous for surveys from the point of view of cost and speed. Several studies conducted in Brazil and the USA show that the sensitivity of this strategy is good for the self-reported diagnoses of hypertension ${ }^{26,27}$.

No differences were detected in the trends of hypertension and diabetes throughout the investigated period. Those conditions were most often diagnosed in individuals without private health insurance, which might be accounted for by their poorer access to health promotion habits, such as healthy eating and practice of physical activity. The possibility of access to primary care and the opportunity of diagnosis at SUS primary care facilities is emphasized ${ }^{28}$.

The frequency of physical activity was higher among the population with private health insurance, while that of physical inactivity was similar in both groups. Some studies found associations between physical activity with more schooling, higher income and health insurance coverage $\mathrm{e}^{29,30}$. Populations with better socioeconomic conditions have wider access to information on healthy habits and to private facilities for exercising can purchase healthy foods such as fruits, legumes and vegetables and have more knowledge of the negative effects of smoking, among other disease factors ${ }^{9}$. Despite their unfavorable circumstances, the level of physical activity increased among the population without health insurance coverage, attesting to a reduction in access inequalities in this regard. The relevance attributed to population-based programs to promote physical activity, including the establishment of specific areas for exercising in the community, such as the Health Academy Program, is worth mentioning, as is the funding for municipal physical activity programs, in addition to the encouragement given to exercising by healthcare professionals, which might support these changes ${ }^{31}$.

Self-assessed state of health is an important indicator that is used worldwide ${ }^{32,33}$. In general, individuals with higher income and educational levels tend to better assess their state of health ${ }^{32,33}$, which might account for the fact that the population without health insurance coverage rated their state of health poor almost three times more often compared to the insured population. In addition, the vast majority of the insured population is inserted in the job market and, thus, is younger, with consequent better self-assessed state of health.

Both overweight and obesity exhibited increasing trends in both groups, which shows that the problem of excess weight is general, affecting all social groups. The obesity epidemic is a global phenomenon resulting from complex causes, including increased consumption of high-calorie density processed foods and reduced levels of physical activity ${ }^{34,35}$. It is worth noting that the prevalence of excess weight did not increase from 2012 to 2013 in either group. Although this finding must be reassessed in the future, it already seems promising.

The variables alcohol abuse and drinking and driving remained stable throughout the investigated period. The frequency of drinking and driving was higher among the population with private health insurance, which might be accounted for by their greater income, which allows them to own cars. Data from Vigitel indicate that the frequency of drinking and driving is higher among the population with more schooling ${ }^{11}$.

This study has some limitations, one of which derives from the fact that the data were collected in phone interviews performed only with individuals with access to landlines, which might hinder the participation of low-income individuals. Nevertheless, that possible bias was neutralized by the application of weights to equate the distributions of the Vigitel and Census populations. The cross-sectional design of the study did not allow inferring temporal cause-effect relationships. Therefore, we cannot claim that access to health insurance coverage reduces the exposure to risk or that individuals particularly concerned with their own health tend to seek such coverage. 


\section{Conclusions}

This study was the first analysis of the trends exhibited by Vigitel indicators in the population with or without private health insurance from all Brazilian capitals. This study is fully justified by the relevance of monitoring indicators of risk and protection factors for NCDs, morbidity and access to screening tests in various social segments aiming at the establishment of public policies for promotion and prevention and at the promotion of equity. Differences were detected in the lifestyles of adults with or without health insurance coverage, the former of which exhibited healthier habits. Differences were also detected in the access to screening tests, which was wider among the insured population; however, the performance of mammograms increased among the uninsured women and stabilized among the insured ones during the investigated period. The increase in the performance of mammograms by uninsured women might reflect the efforts made to expand SUS services and is relevant for the reduction of inequality.

\section{Collaborators}

Malta DC participated in the study design, reviewed the literature, performed data analysis, drafted the initial version and approved the final version of the present article; RTI Bernal participated in the study design, performed data and statistical analysis and approved the final version of the present article; M Oliveira made substantial contributions and approved the final version of the present article. 


\section{References}

1. World Health Organization (WHO). Global status report on noncommunicable diseases 2010 [Internet]. Geneva: World Health Organization; 2011. [acrescentar data de acesso: ano mês dia]. Disponível em: http:// www.who.int/nmh/publications/ncd_report2010/en/

2. Schmidt MI, Duncan BB, Azevedo e Silva G, Menezes AM, Monteiro CA, Barreto SM, Chor D, Menezes PR. Chronic non-communicable diseases in Brazil: burden and current challenges. The Lancet 2011; 377(9781):1949-1961.

3. Malta DC, Morais Neto OL, Silva Junior JB. Apresentação do plano de ações estratégicas para o enfrentamento das doenças crônicas não transmissíveis no Brasil, 2011 a 2022. Epidemiol. Serv. Saúde 2011; 20(4):425438.

4. World Health Organization (WHO). Global action plan for the prevention and control of NCDs 20132020 [internet]. Geneva: WHO; 2013. [cited 2014 Jan 27]. Available from: http://www.who.int/nmh/events/ ncd_action_plan/en/

5. Bonita R, Magnusson R, Bovet P, Zhao D, Malta DC, Geneau R, Suh Il, Thankappan KR, Mckee M, Hospedales J, De Courten M, Capewell S, Beaglehole R. Country actions to meet UN commitments on noncommunicable diseases: a stepwise approach. Lancet 2013; 381(9866):575-584.

6. Instituto Brasileiro de Geografia e Estatística (IBGE). Pesquisa Nacional por Amostra de Domicílios (PNAD 2008). Um panorama da saúde no Brasil: acesso e utilização dos serviços, condições de saúde: 2008. Rio de Janeiro: IBGE; 2010.

7. Ahluwalia JB, Bolen J, Garvin B. Health insurance coverage and use of selected preventive services by working age women, BRFSS 2006. J Womens Health (Larchmt) 2007; 16(7):935-940.

8. Nelson KM, Chapko MK, Reiber G, Boylo EJ. The association between health insurance coverage and diabetes care; data from the 2000 behavior risk factor surveillance system. Health Serv Res 2005; 40(2):361-372.

9. Lima e Costa MF. Estilos de vida e uso de serviços preventivos de saúde entre adultos filiados ou não a plano privado de saúde (inquérito de saúde de Belo Horizonte). Cien Saude Colet 2004; 9(4):857-864.

10. Malta Deborah Carvalho, Bernal Regina Tomie Ivata. Comparação dos fatores de risco e proteção de doenças crônicas na população com e sem planos de saúde nas capitais brasileiras, 2011. Rev. bras. epidemiol. [serial on the Internet]. 2014 [cited 2014 Sep 02]; 17(Supl. 1):241-255. Available from: http:// www.scielo.br/scielo.php?script=sci_arttext\&pid= S1415-790X2014000500241\&lng=en. http://dx.doi.org /10.1590/1809-4503201400050019.

11. Brasil. Ministério da Saúde (MS). Secretaria de Vigilância em Saúde. Vigitel Brasil 2012: Vigilância de fatores de risco e proteção para doenças crônicas por inquérito telefônico. Brasília: MS; 2013.

12. Bernal R. Inquéritos por telefone: inferências válidas em regiões com baixa taxa de cobertura de linhas residenciais [tese]. São Paulo: USP; 2011.

13. Izrael D, Hoaglin, DC, Battaglia MP. A SAS Macro for Balancing a Weighted Sample. Proceedings of the Twenty-Fifth Annual SAS Users Group International Conference, Paper 275, 2000.
14. Paula GA. Modelos de Regressão com apoio computacional. São Paulo: IME-USP; 2004.

15. Hayward RA, Shapiro MF, Freeman HE, Corey C. Inequalities in health services among insured Americans. Do working-age adults have less access to medical care than the elderly? N Engl J Med 1988; 318(23):15071512.

16. Hagdrup NA, Simoes EJ, Browson, RC. Health care coverage: traditional and preventive measures and associations with chronic disease risk factor. J Community Health 1997; 22(5):387-399.

17. Lima-Costa MF, Guerra HL, Firmo JO, Vidigal PG, Uchoa E, Barreto SM. The Bambuí Health and Ageing Study (BHAS): private health plan and medical care utilization by older adults. Cad Saude Publica 2002; 18(1):177-186.

18. Lima-Costa MA. A escolaridade afeta, igualmente, comportamentos prejudiciais à saúde de idosos e adultos mais jovens?: Inquérito de Saúde da Região Metropolitana de Belo Horizonte, Minas Gerais, Brasil. Epidemiologia e Serviços de Saúde 2004; 13(4):201-208.

19. Comissão sobre Determinantes Sociais da Saúde (CSDH). Iniqüidades em saúde no Brasil, nossa mais grave doença. [acessado 2009 jun (informar o dia)]. Disponível em: http://www.determinantes.fiocruz.br/ iniquidades.htm

20. Brasil. Ministério da Saúde. Instituto Nacional do Cancer. Programa Nacional de Controle do Câncer do Colo do Útero. [acessado 2013 set 4]. Disponível em: http:// wwwl.inca.gov.br/inca/Arquivos/PROGRAMA_UTERO _internet.PDF.

21. Brasil. Ministério da Saúde (MS). Instituto Nacional do Cancer (Inca). Programa Nacional de Controle do Câncer de mama. [acessado 2013 set (dia)]. Disponível em: http://www2.inca.gov.br/wps/wcm/connect/acoes _programas/site/home/nobrasil/programa_controle _cancer_mama/deteccao_precoce

22. Santos IS, Ugá MAD, Porto SM. O mix público-privado no Sistema de Saúde Brasileiro: financiamento, oferta e utilização de serviços de saúde. Cien Saude Colet 2008; 13(5):1431-1440.

23. Brasil. Ministério da Saúde. Portaria SAS/MS no 827, de 3 de julho de 2013. Programa nacional de qualidade da mamografia. Diário Oficial da União 2013; 4 jul.

24. Silva JB, Magalhães HM. Initiatives in cancer control from Brazil's Ministry of Health. Lancet Oncol 2013; 14(5):385-386.

25. Malta DC Silva JB O Plano de Ações Estratégicas para o Enfrentamento das Doenças Crônicas Não Transmissíveis no Brasil e a definição das metas globais para o enfrentamento dessas doenças até 2025: uma revisão. Epidemiol. Serv. Saúde 2013; 22(1):151-164.

26. Lima-Costa MF, Peixoto SV, Firmo JO. A Validade da hipertensão arterial autoreferida e seus determinantes (Projeto Bambuí). Rev Saude Publica 2004; 38(5):637642.

27. Vargas CM, Burt VL, Gillum RF, Pamuk ER. Validity of self-reported hypertension in the National Health and Nutrition Examination Survey III, 1988-1991. Prev Med 1997; 26(5 Pt 1):678-685. 
28. Ferreira SRG, Moura EC, Malta DC, Sarno F.Hipertensão arterial autorreferida no Brasil: freqüência e fatores associados. RSP 2009; 43(2):98-106.

29. Florindo AA, Hallal PC, Moura EC, Malta DC. Prática de atividades físicas e fatores associados em adultos, Brasil, 2006. Rev Saude Publica 2009; 43(Supl. 2):65-73.

30. Knuth AG, Malta DC, Dumith SC, Cimar A, Morais Neto OL, Temporão JG, Penna G, Hallal PC. Prática de atividade física e sedentarismo em brasileiros: resultados da Pesquisa Nacional por Amostra de Domicílios (PNAD) 2008. Cien Saude Colet 2011; 16(9):3697-3705.

31. Malta DC, Silva Júnior JB. Policies to promote physical activity in Brazil. Lancet 2012; 380(9838):195-196.

32. Molarius A, Berglund K, Eriksson C, Lambe M, Nordström E, Eriksson H, Eriksson HG, Feldman I. Socioeconomic conditions, lifestyle factors, and self-rated health among men and women in Sweden. Eur J Public Health 2006; 17(3):125-133.

33. Dachs JNW, Santos APR. Autoavaliação do estado de saúde no Brasil: análise dos dados da PNAD/2003. Cien Saude Colet 2006; 11(4):887-894.

34. Reporter of World Health Organization (WHO) Consultation. Obesity: preventing and managing the global epidemic. Geneva: WHO; 2000. Technical reporter Series. No 894. 2000.

35. International Association for the Study of Obesity (IASO) (2013) Adult overweight and obesity in the European Union (EU27). [acessado 2013 nov 02]. Disponível em: http://www.iaso.org/resources/world-map -obesity/ Accessed novembro 2013.

Article submitted 09/23/2014

Approved 11/05/2014

Final version submitted 11/07/2014 